\title{
Autoantibodies in childhood scleroderma
}

\author{
R M BERNSTEIN, ${ }^{1}$ R S PEREIRA, ${ }^{2}$ A J HOLDEN, ${ }^{2}$ C M BLACK, ${ }^{2}$ \\ A HOWARD, ${ }^{3}$ AND B M ANSELL ${ }^{3}$
}

From the ${ }^{1}$ Royal Postgraduate Medical School, London, W12; the ${ }^{2}$ West Middlesex University Hospital, Isleworth, Middlesex; and the ${ }^{3}$ Clinical Research Centre, Watford Road, Harrow, Middlesex

SUMmARY The clinical presentation of scleroderma in childhood is even more varied than in adult life. This study of 19 children shows that antinuclear antibodies (ANA) detected on the $\mathrm{HEp}_{2}$ cell substrate are just as common as in the adult disorders. All seven children with diffuse scleroderma or acrosclerosis were ANA positive, as were eight of the 12 with more localised disease. Antinucleolar antibodies were particularly frequent (58\% overall), but anticentromere antibody was not observed. Enzyme-linked immunosorbent assays (ELISAs) for antibodies to collagen types I-V, in contrast to adult scleroderma, gave normal results in all childhood cases.

Key words: systemic sclerosis, children, antinuclear antibodies, antinucleolar antibodies, anticentromere antibody, anticollagen antibodies.

Antinuclear antibodies in considerable titre were described in four of nine cases of childhood scleroderma reported in $1976 ;^{1}$ although low titres were found in the remaining five, none had antibodies to DNA or extractable nuclear antigens or low complements. In contrast to the findings of Hanson et al. ${ }^{2}$ we did not find rheumatoid factor in our children with local scleroderma.

Antibodies to collagen types I and IV have been described in adult scleroderma, ${ }^{3}$ and other collagen antibodies have been shown in adults with rheumatic diseases ${ }^{4-6}$ and with a variety of non-rheumatic disorders. ${ }^{7-9}$ Some previous assays of apparent collagen antibody have been criticised on the grounds that fibronectin (cold insoluble globulin) could affect binding. ${ }^{10}$ Assays were therefore performed at room temperature in our studies, and fibronectin levels were measured independently by radial immunodiffusion.

The present report concerns a study of autoantibodies in children with a variety of the different scleroderma syndromes seen in childhood.

\section{Patients and methods}

Nineteen children were studied. Three had diffuse adult-type cutaneous scleroderma with Raynaud's

Accepted for publication 21 February 1985.

Correspondence to Dr R M Bernstein, Rheumatism Research Centre, The Royal Infirmary, University of Manchester, Oxford Road, Manchester M13 9WL. phenomenon; all three had serious contractures, in addition to which one had visceral involvement (kidney and heart) and another had begun as mixed connective tissue disease with antibody to the nuclear RNP antigen at that time before progressing to severe scleroderma with calcinosis. Four patients had acrosclerosis with calcinosis and Raynaud's phenomenon. In the remaining 12 children scleroderma was limited to sclerodactyly (one patient), linear morphea 'en coup de sabre' (four patients), multiple morphea (two patients), a single patch of morphea (one patient), and multiple cutaneous nodules consisting of fibrinoid material, ${ }^{1}$ leading to skin tightness of hands and feet (four patients).

\section{ANTINUCLEAR ANTIBODIES}

Antinuclear antibodies (ANA) were examined on the $\mathrm{HEp}_{2}$ cell substrate (Antibodies Inc, Davis, CA), with serum diluted 1:40 in phosphate-buffered saline and fluorescein isothiocyanate conjugated sheep antihuman IgG (Wellcome Laboratories, Beckenham, Kent). Nuclear, nucleolar, cytoplasmic, and mitotic cell staining was recorded with brightness on a $1-4+$ scale. Under similar conditions $15 \%$ of 60 healthy adult control sera were ANA positive. The methods and variety of staining patterns revealed have been described previously. ${ }^{11}$

COLLAGEN ANTIBODIES

Serum antibodies to collagens were measured by an ELISA technique. Flat-bottom microtitre plates 
(Immulon, Dynatech) were coated at $4^{\circ} \mathrm{C}$ with 200 $\mathrm{ng} /$ well of purified human collagen. Human collagen types $\mathrm{I}-\mathrm{V}$ were used, both in native form and after being denatured by heating at $56^{\circ} \mathrm{C}$ for 30 minutes, and were dissolved for coating in $0.05 \mathrm{M}$ bicarbonate buffer $\mathrm{pH} 9 \cdot 6$. After coating overnight wells were washed with phosphate-buffered saline pH 7.4 with added $0.05 \%$ Tween 20 (PBS-Tween). Test sera were diluted 1:100 in PBS-Tween and 200 $\mu \mathrm{l} /$ well was added; the plates were then incubated for four hours at room temperature. Wells were washed twice with PBS-Tween. The conjugate was then added as $200 \mu \mathrm{l} /$ well of alkaline phosphatase labelled rabbit antihuman IgG (Sigma) diluted $1: 1000$ in PBS-Tween with $0.1 \%$ bovine serum albumin. The plates were incubated overnight at $4^{\circ} \mathrm{C}$, and wells were washed twice with PBS-Tween. Substrate was added as $200 \mu \mathrm{l} /$ well of $p$-nitrophenyl phosphate (Sigma) $1 \mathrm{mg} / \mathrm{ml}$ in $0.1 \mathrm{M}$ glycine buffer pH 10.4 , with $0.001 \mathrm{M} \mathrm{MgC1}_{2}$ and $0.001 \mathrm{M} \mathrm{ZnC1}_{2}$. After incubation for 30 minutes in the dark at room temperature the reaction was stopped with $50 \mu \mathrm{l}$ saturated $\mathrm{NaOH}$. The optical density at $410 \mathrm{~nm}$ was read with a manual plate-reading spectrophotometer (MiniReader II, Dynatech) with computerised output for statistical analysis. Sera from the nineteen patients described were tested in duplicate at 1:1000 dilution, and the results compared with a panel of 20 control sera from age-matched normal children and with 20 normal adult sera. The mean and standard deviation for each collagen in each group of subjects were calculated, and a normal range was constructed for each collagen type. Results were expressed as arithmetic means and standard deviations of optical densities of wells from each plate. Samples were tested together in a random array and could be compared within a plate.

FIBRONECTIN ASSAY

Fibronectin levels in the serum samples were measured by radial immunodiffusion. $100 \mu \mathrm{l}$ of rabbit IgG antibody to human fibronectin (Dakopatts) was added to $12 \mathrm{ml} 1 \%$ agarose containing $0.02 \mathrm{M}$ barbitone and $0.04 \mathrm{M}$ ethylenediaminetetra-acetic acid buffered to $\mathrm{pH} \mathbf{8 \cdot 6}$. Wells were filled with neat serum; replicate standard serum dilutions were included on the plate. After diffusion for 24 hours at room temperature the plate was dried, washed, and stained with Coomassie Blue. Fibronectin concentrations were measured by comparison of precipitate diameters with the standard curve.

\section{Results}

ANTINUCLEAR ANTIBODIES

Fifteen $(79 \%)$ of the 19 sera gave nuclear staining,

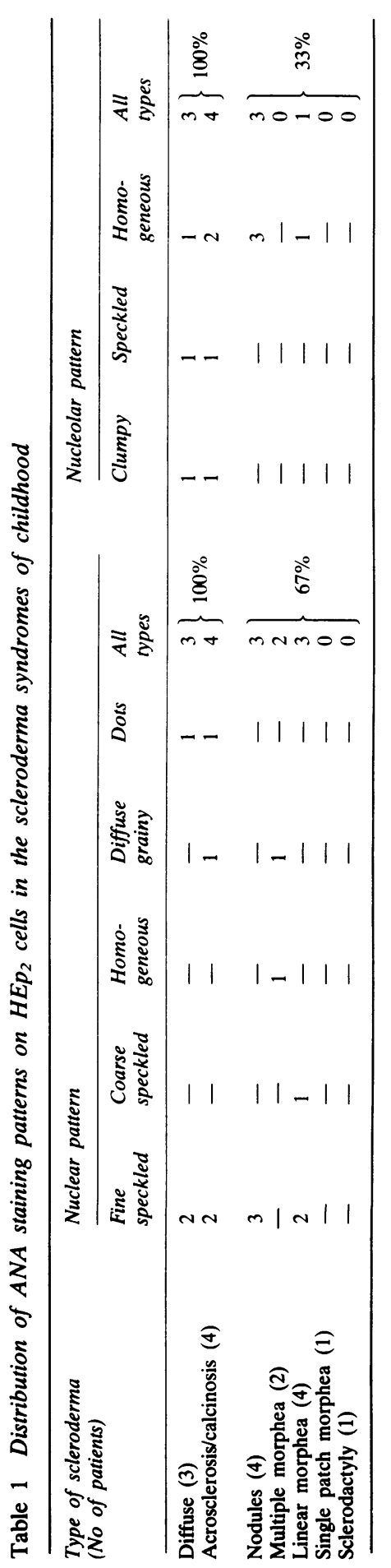


which was finely speckled in nine, diffusely grainy in two, homogeneous in one, dots (probably in these cases micronucleoli) in two, and coarsely speckled in one. Eleven sera $(58 \%)$ showed nucleolar staining, which was clumpy in two (associated with the micronucleolar staining in both cases), speckled in two, and homogeneous in seven (associated with fine speckled nuclear staining in eight and the diffusely grainy pattern in one). Overall, 11 sera gave staining of brightness $>2+$, four gave $1+$ staining, and four were negative. Only one serum gave cytoplasmic staining, and none contained anticentromere antibody.

A combination of antinuclear and antinucleolar antibodies was observed in all seven patients with either diffuse scleroderma or acrosclerosis and in three of the four patients with nodules (Table 1). Three of the four patients with linear morphea were ANA positive (only one with antinucleolar antibody), as were both patients with multiple morphea. The ANA negative patients thus comprised one of four patients with nodules, one of four with linear scleroderma, the one patient with isolated sclerodactyly, and the one case with a single patch of morphea. All patients with diffuse scleroderma or acrosclerosis and two-thirds of the patients with localised scleroderma were ANA positive.

\section{COLLAGEN ANTIBODIES}

It can be seen from Table 2 that there were no significant differences between the measured collagen antibody levels in the three groups tested. The number of samples with values more than one SD higher than the mean was similar for each group of subjects, and further analysis showed that there was no evidence that individual patients differed from age-matched normal controls.

\section{FI B R O N E C T IN}

The fibronectin concentration in each serum sample was compared with the collagen antibodies. No correlation was detected (Table 3).
Table 3 Correlation coefficients of serum fibronectin concentrations measured by immunodiffusion, with collagen antibodies measured by ELISA OD ${ }_{410 \mathrm{~nm}}{ }^{*}$

\begin{tabular}{lcc}
\hline Collagen type & Native & Denatured \\
\hline I & -0.008 & -0.006 \\
II & 0.25 & 0.25 \\
III & 0.05 & 0.01 \\
IV & 0.31 & 0.007 \\
V & 0.29 & 0.002 \\
\hline
\end{tabular}

${ }^{*} \mathrm{OD}_{410 \mathrm{~nm}}=$ optical density at $410 \mathrm{~nm}$.

\section{Discussion}

Antinuclear antibodies are an uncommon finding in childhood, and only $10 \%$ of over 1400 patients seen in one paediatric immunology/rheumatology clinic were ANA positive (titre $\geqslant 20$ on rat tissue). ${ }^{12}$ Most of those ANA were associated with rheumatic disease, chiefly systemic lupus erythematosus and juvenile arthritis.

Sera from $96 \%$ of adults with systemic sclerosis and $73 \%$ with morphea were ANA positive when tested on a tissue culture cell substrate. ${ }^{11} 1314$ Scleroderma is a rare condition in childhood. The present study shows that the prevalence of antinuclear and antinucleolar antibodies is as high as in adult scleroderma. Thus all seven children with diffuse scleroderma or acrosclerosis and eight $(67 \%)$ of the 12 with localised scleroderma had ANA.

Anticentromere antibody is a common finding in adult CREST syndrome (calcinosis, Raynaud's phenomenon, oesophageal dysmotility, sclerodactyly, telangiectasia), ${ }^{13}{ }^{15-17}$ yet this antibody was not found in any of the children's sera, though several had calcinosis, Raynaud's phenomenon, and acrosclerosis. A larger study might reveal anticentromere antibody in childhood. Alternatively, it may be that CREST syndrome is a purely adult disease, evolving as it usually does from a long prodrome of Raynaud's phenomenon.

Table 2 ELISA results expressed as mean $O D_{+10 ~}$ mm $^{*}$ with $1 S D$

\begin{tabular}{|c|c|c|c|c|c|c|c|c|c|c|c|}
\hline & & \multicolumn{5}{|c|}{ Native collagen type } & \multicolumn{5}{|c|}{ Denatured collagen type } \\
\hline & & $I$ & $I I$ & $I I I$ & $I V$ & $\boldsymbol{V}$ & $I$ & $I I$ & $I I I$ & IV & $\boldsymbol{V}$ \\
\hline Juvenile (19) & Mcan & 0.91 & $0 \cdot 86$ & 0.91 & $1 \cdot 44$ & 0.51 & 0.97 & 0.57 & 0.72 & 0.63 & $0 \cdot 82$ \\
\hline scleroderma & SD & $0 \cdot 30$ & $0 \cdot 26$ & 0.33 & $0 \cdot 58$ & $0 \cdot 14$ & $0 \cdot 32$ & $0 \cdot 29$ & $0 \cdot 21$ & $0 \cdot 19$ & $0 \cdot 59$ \\
\hline Juvenile $(20)$ & Mcan & 0.91 & 0.88 & 0.95 & $1 \cdot 34$ & 0.58 & $1 \cdot 01$ & $0 \cdot 64$ & 0.79 & 0.57 & 0.73 \\
\hline Adult (20) & Mcan & 0.90 & 0.82 & 0.99 & $1 \cdot 26$ & 0.55 & 0.97 & 0.50 & 0.71 & 0.72 & 0.63 \\
\hline normal & SD & $0 \cdot 33$ & $0 \cdot 28$ & 0.33 & 0.45 & 0.18 & 0.40 & 0.23 & $0 \cdot 26$ & 0.29 & $0 \cdot 24$ \\
\hline
\end{tabular}

${ }^{*} O D_{411}{ }_{n m}=$ optical density at $410 \mathrm{~nm}$. 
Anti-Scl-70 antibody (recognised by immunodiffusion) is a marker for systemic sclerosis found in up to $20 \%$ of adult cases. ${ }^{11} 131617$ Although we did not look for anti-Scl-70 directly in this study, we did note in two patients the diffusely grainy ANA pattern that is often associated with that antibody. ${ }^{11}$

Antinucleolar antibodies have been reported in $43 \%$ of adults with systemic sclerosis and $41 \%$ with localised scleroderma, frequencies much higher than in other systemic rheumatic diseases. ${ }^{11} 1416$ Among the children with scleroderma the prevalence of these antibodies was particularly high, including all seven patients with diffuse disease or acrosclerosis, and $33 \%$ of those with localised involvement. We have also observed antinucleolar antibody in two out of three patients with sclerodermatous graftversus-host disease but not at all among patients with the scleroderma-like reaction to vinyl chloride (RMB, unpublished data). The link between scleroderma and the nucleolus remains obscure but could be of pathogenetic or aetiological significance. Within the cells nucleoli form around the DNA of the short arms or 'satellites' of the acrocentric D and $\mathrm{G}$ group chromosomes at their nucleolar organiser regions. One of the cytogenetic abnormalities found frequently in leucocytes from patients with scleroderma is increased 'satellite association' or clumping together of $D$ and $G$ group chromosomes in metaphase, ${ }^{18}$ and it is intriguing to consider whether antinucleolar antibodies might be involved in this process. Indeed, the speckled pattern antinucleolar antibody binds to a nucleolar organiser region protein (RNA polymerase I) ${ }^{19}$ On present evidence it seems unlikely that autoantibodies generally enter cells to cause damage directly; rather it may be that whatever agent causes the satellite associations also renders the nucleolus immunogenic.

Fibronectin in clotted blood samples has been reported to be a source of error in measuring collagen antibodies. ${ }^{1020}$ Our study shows that there is no correlation between serum fibronectin and antibodies measured to collagen types I to $\mathrm{V}$; using a two-tailed test of the probability that such a link existed, a correlation coefficient of $>0.444$ would be needed even at the $5 \%$ level, and this is not achieved (Table 3).

There is no apparent difference in antibody levels to any of the collagen types tested when comparison is made with age-matched or adult controls. In particular no cases in this study had significantly raised antibodies to native or denatured collagen type II. Collagen antibodies may not have pathogenic significance in the childhood disease.
References

1 Ansell B M, Nasseh G A, Bywaters E G L. Scleroderma in childhood. Ann Rheum Dis 1976; 35: 189-97.

2 Hanson V, Kornreich H, Drexler E, Johnson G D, Macphersoro G A. Some immunologic considerations in focal scleroderm and progressive systemic sclerosis in children. Pediatr Res 1974 8: 806-9.

3 Mackel A M, DeLustro F, Harper F E, LeRoy E C. Antibodie to collagen in scleroderma. Arthritis Rheum 1982; 25: 522-31

4 Steffen C, Timpl R. Antigenicity of collagen and its application? in the serological investigation of rheumatoid arthritis sera. $\ln \overrightarrow{\mathbf{b}}$ Arch Allergy Appl Immunol 1963; 22: 333-49.

5 Michaeli D, Fudenberg H H. Antibodies to collagen in $\overrightarrow{\vec{w}}$ patients with emphysema. Clin Immunol Immunopathol 1974 3: $187-92$.

ญิ

6 Andriopoulos N A, Mestecky J, Miller E J, Bradley E Lę Antibodies to native and denatured collagens in sera of patient 5 with rheumatoid arthritis. Arthritis Rheum 1976; 19: 613-7.

7 Wells J V, Michaeli D, Fudenberg H H. Antibodies to humar collagen in subjects with selective IgA deficiency. Clin Ex/O Immunol 1973; 13: 203-8.

8 Michaeli $\mathrm{D}$, Fudenberg $\mathrm{H} \mathrm{H}$. The incidence and antigeni? specificity of antibodies against denatured human collagen in rheumatoid arthritis. Clin Immunol Immunopathol 1974; 2.7 153-9.

9 McAdam K P W J, Fudenberg H H, Michaeli D. Antibodies tô collagen in patients with leprosy. Clin Immunol Immunopathof 1978; 9: 16-21.

10 Beard H K, Lea D J, Ryvar R. Anomalous reactions in thøo haemagglutination assay for anti-collagen antibodies: studies on patients with rheumatoid arthritis or chronic low back pain. Immunol Methods 1979; 31: 119-28.

11 Bernstein R M, Steigerwald J C, Tan E M. Association of antinuclear and antinucleolar antibodies in progressive systemio sclerosis. Clin Exp Immunol 1982; 48: 43-51.

12 Chudwin D S, Amman A J, Cowan M J, Wara D W Significance of a positive antinuclear antibody test in a pediatric population. Am J Dis Child 1983; 137: 1103-6.

13 Tan E M, Rodnan G P, Garcia I, Moroi Y, Fritzler M Peebles C. Diversity of antinuclear antibodies in progressive systemic sclerosis. Anti-centromere antibody and its relationship. to CREST syndrome. Arthritis Rheum 1980; 23: 617-25.

14 Takehara K, Moroi Y, Nakabayashi Y, Ishibashi Y. Antinuō clear antibodies in localized scleroderma. Arthritis Rheum 19836 26: 612-6.

15 Fritzler M J, Kinsella T D, Garbutt E. The CREST syndrome: ip distinct serological entity with anticentromere antibodies. $A m$ \& Med 1980; 69: 520-6.

16 Bernstein R M, Bunn C C, Hughes G R V, Francoeur A M Mathews M B. Protein and RNA antigens in autoimmune disease. Mol Biol Med 1984; 2: 105-20.

17 Catoggio L J, Bernstein R M, Black C M, Hughes G R V. Maddison $P$ J. Serological markers in progressive system sclerosis: clinical correlations. Ann Rheum Dis 1983; 42: 23-7.

18 Sherer G K, Jackson B B, LeRoy E C. Chromosome breakage and sister chromatid exchange frequencies in scleroderme Arthritis Rheum 1981; 24: 1409-13.

19 Reimer G, Rose K M, Tan E M. Association of novel proteif antigens reactive with IgG-antinucleolar antibodies and diffuse scleroderma [Abstract]. Arthritis Rheum 1985; 28: S33.

20 Adelmann B, Schoning B. Binding of native and denatured collagen to immunoglobulins and cold insoluble globulin serum of patients undergoing orthopaedic surgery. Kl⿳⺈⿴囗十灬 Wochenschr 1980; 58: 625-9. 